$1-1-2016$

\title{
A Modest Proposal for Expediting Manuscript Selection at Less Prestigious Law Reviews
}

Joseph S. Miller

University of Georgia School of Law, getmejoe@uga.edu

bS bepress

\section{Repository Citation}

Joseph S. Miller, A Modest Proposal for Expediting Manuscript Selection at Less Prestigious Law Reviews (2016),

Available at: https://digitalcommons.law.uga.edu/fac_artchop/1077

This Article is brought to you for free and open access by the Faculty Scholarship at Digital Commons @ University of Georgia School of Law. It has been accepted for inclusion in Scholarly Works by an authorized administrator of Digital Commons @ University of Georgia School of Law. Please share how you have benefited from this access For more information, please contact tstriepe@uga.edu. 


\title{
A Modest Proposal for Expediting Manuscript Selection at Less Prestigious Law Reviews
}

Joseph Scott Miller ${ }^{\dagger}$

\begin{abstract}
As one student remarked, in a recent study of law review editors, "[a]uthors are brutal. They are so calculating it's scary. They would sell you into slavery if Harvard asked them to ... ."1

Law review publishing is weird. Any system that runs on massive simultaneous submission is bound to be. ${ }^{2}$
\end{abstract}

The conventional wisdom, in project management circles, is that one cannot obtain a good outcome quickly at low cost. When it comes to these three desiderata, you get only two at a time; "fast, cheap, and good" is not on offer. Or so we are told.

But what about selecting from among the many unsolicited manuscripts submitted to every student-run general law review? Can an editorial board cull-at high speed and low cost-a group of well-reasoned, well-written articles from the torrents that arrive each March and August through ExpressO and Scholastica digital-submission pipelines? Can it get results that are fast, cheap, and good? A board can do so, if it is willing to embrace, fully, the dynamics of professors' requests for expedited review in the market for publishing prestige. This essay sketches the strategy.

Start with five givens that set the frame ...

- Most general law reviews publish about four issues per year, and most issues of a general law review publish about five articles. Assuming a review is not publishing invited pieces, symposia, or the like, that translates to a target of 20 articles under contract. (If the review is publishing invited pieces, the target number is smaller still.)

- Most general law reviews receive hundreds, if not thousands, of unsolicited manuscripts a year. The 20 -article target a review must hit is thus but a small fraction of what it receives as a matter of course. Even a small yield will be sufficient.

- The prestige of U.S. law schools, reflected in the U.S. News rankings, is strongly positively correlated with the prestige of their general law reviews, reflected in the frequency with which the articles in the reviews are subsequently cited. ${ }^{3}$

\footnotetext{
${ }^{\dagger}$ Professor, University of Georgia School of Law. (C) 2016 Joseph Scott Miller.

${ }^{1}$ Leah M. Christensen \& Julie A. Oseid, Navigating the Law Review Article Selection Process: An Empirical Study of Those With All the Power-Student Editors, 59 S.C. L. REV. 207 (2007) (ellipsis in original).

2 James Grimmelmann, Scholastica Sunt Servanda, The Laboratorium (2d ser.), Apr. 14, 2015, available at http://2d.laboratorium.net/post/116408726220/scholastica-sunt-servanda.

${ }^{3}$ See Alfred L. Brophy, The Relationship Between Law Review Citations and Law School Rankings, 39 ConN. L. REV. 43, 48-49 (2006).
} 
- Law professors generally prefer to publish a given article in a more prestigious law review. Most will act on that preference when they can do so.

- In a quest to place their articles in more prestigious publishing venues, many law professors frequently submit their manuscripts to multiple reviews for simultaneous consideration. ${ }^{4}$ And for at least about 30 years now, law professors typically shop any publication offers they receive to editors at the more prestigious journals, where-as I have said-they would prefer to publish. ${ }^{5}$ Law review editors, for their part, have come to use the expedite requests - predicated on genuine offers received from less prestigious law reviews after substantive consideration - as one of their screening mechanisms in deciding what to focus on next for more thorough consideration. ${ }^{6}$

In this context, how can editorial boards at less prestigious law reviews get the greatest editorial benefit at lowest cost? It turns out to be rather simple, in fact.

The strategy has three interwoven elements. It would not make sense to use the elements piecemeal; I have designed the proposal as a coherent, integrated whole. The key is to realize that, in this largely industrial (rather than personal or scholarly) process, a journal should focus its scarce individualized-review attention on submissions from authors who are predictably more likely to accept an offer of publication. Any approach that ignores the data about which authors are more likely to accept and which authors are more likely to reject-likelihoods pegged to authors' institutional affiliations, which all the journals can readily see-wastes precious student time and attention for no good reason.

First, the editorial board identifies its current prestige-point among prospective authors, by determining the institutional affiliations of the law-professor authors who have published in the journal over the last seven to ten years. In determining prestigepoint, the review should count only the pieces that were unsolicited manuscripts, and thus were exposed to the push and pull of the March and August trading periods before

\footnotetext{
${ }^{4}$ See Nancy Levit, Scholarship Advice for New Law Professors in the Electronic Age, 16 WIDENER L.J. 947, 975-76 (2007) (describing multi-journal submission). This would be cause for scandal in most academic fields, but in law it is the norm.

${ }^{5}$ See Erik M. Jensen, The Law Review Manuscript Glut: The Need for Guidelines, 39 J. LEGAL EDUC. 383, 384-85 (1989) (describing the process); Jordan H. Leibman \& James P. White, How the Student-Edited Law Journals Make Their Publication Decisions, 39 J. LEGAL EDUC. 307, 409 (1989) (same). As one professor recently put it, "[a]n offer to publish does not bind the author, but rather invites the author to leverage the offer by making an 'expedite' request with a higher-ranked law journal." Albert H. Yoon, Editorial Bias in Legal Academia, 5 J. LEGAL ANALYSIS 309, 311 (2013).

${ }^{6}$ See Nathan H. Saunders, Student-Edited Law Reviews: Reflections and Responses of an Inmate, 49 DUKE L.J. 1663, 1666 (2000) ("Finally, and most importantly, let the editors of other law journals do your work for you; that is, concentrate your effort on expedited reviews-articles which have already received an offer from another journal."). In this way, higher-prestige editorial boards partner with higher-prestige professors, helping the professors accept the low-prestige journals' tacit "invitations," Yoon, id., to shop their articles up the chain.
} 
landing, finally, in the review's pages. For example, Gamma Law Review might find that, from 2005 to 2015 , only $1 \%$ of its authors were at a top-30 law school when they accepted the journal's offer of publication, and only $5 \%$ of its authors were at a top-50 law school when they accepted. ${ }^{7}$ For GLR, it makes sense to target the submissions of law professors who are at schools below the top 50. (If the percentages change in the future, the prestige-point and related focus of GLR's efforts can change along with them.) For its part, Delta Law Review might find that, in the same period, $1 \%$ of its authors were at top-10 schools, and 5\% of its authors were at top-20 schools. For DLR, it makes sense to target the submissions of law professors who are at law schools below the top 20. Each school uses its own rolling decade of author $\bullet$ school data to set a prestige-point that can help direct editorial resources.

Second, the board sorts incoming manuscripts according to the institutional affiliations of the authors who submit them, using the review's own prestige-point to draw the line that separates the manuscripts into two categories. The manuscripts in the resulting batches receive different editorial treatment and correspondingly different types of publication offers. Along the way, editorial effort is much more closely calibrated to the likely pay-off to the journal from having made an offer.

Professors at schools above the journal's prestige-point receive ultra-expedited offers, because those professors are extremely unlikely to accept the offers (based on the prior decade's data for that journal, updated annually). In this group, the review offers to publish simply on the basis of the author's institutional affiliation and gives the author two (certainly no more than three) days to accept the offer. ${ }^{8}$ That a professor may shop the offer to more prestigious journals is of no consequence, given that the offer took virtually no effort to provide and is almost certain to be rejected (whether providing it was costly or not). If a professor unexpectedly accepts the offer, the paper is likely to be of a quality broadly similar to the rest of the journal's content ${ }^{9}$ - no cause for worry.

Professors at schools at or below the journal's prestige-point receive individualized editorial review, because these professors are more likely to accept any resulting offers (based, again, on the rolling-decade data). In this group, resulting offers could provide authors a week (or 10 days) to accept, thus allowing time for substantive exchanges

\footnotetext{
${ }^{7}$ It will take a bit of effort to create the first-generation spreadsheet containing these author/school/rank data, but it should take only minimal effort to update it with each new journal issue.

${ }^{8}$ Extensions of time are out of the question, increasing manuscript-tracking costs for no benefit.

${ }^{9}$ See generally Jeffrey L. Harrison \& Amy R. Mashburn, Citations, Justifications, and the Troubled State of Legal Scholarship: An Empirical Study, 3 TEX. A\&M L. REV. 45, 79-80 ("The empirical results show that many articles in a ten-year span are not cited by any court or author, and many that are cited serve no useful function in helping the citing author advance or articulate a new idea, theory, or insight. ... Based on statistics found in this Article and other places, one might conclude that this oversupply is found in the scholarship published in lower ranked journals. The unfortunate truth is that, regardless of their quality, it is unlikely that articles in those publications would be missed. This observation is more compelling when one recalls that this study considered only the top 100 reviews.") (footnote omitted).
} 
between an author and the editorial board. As with the automatic offers, however, these individualized offers should not be extended; the journal obtains no benefit from assisting the author in his or her efforts to shop the piece to more prestigious reviews, and stands to gain articles at the margin (from risk-averse authors) by holding fast.

Happily, the sorting process described above can be automated, or nearly so, such that it diverts little to no editorial attention away from authors more likely to accept the journal's offers. ${ }^{10}$ And on the rare occasion when a high-flying author accepts one of the automated offers, the journal will doubtless be delighted to accommodate the piece. Of course, if authors with that affiliation began to accept automated offers with any frequency, the process of annually updating the journal's presitge-point would shift papers from that school's faculty into the individualized-review category. Automatedoffer bubbles will thus pop nearly as quickly as they form.

Third, the board should disregard all professors' requests for expedited review that are based on fast-expiring automated offers of publication from less prestigious law reviews. These automated offers, as the board well knows, do not reflect any substantive editorial review. As a result, these offers are probative of nothing other than the conferring law review's ability to establish their own prestige-point and correctly channel the piece by the author's institutional affiliation. ${ }^{11}$ The board, moreover, can readily identify the automated offers simply by requiring the requesting author to state how much time elapsed between submitting the piece to the other review and receiving a publication offer from that review.

By taking these three integrated, data-driven steps, the less prestigious law review boards can avoid wasting time carefully considering manuscripts from those who are most likely to shop the offer successfully to a more prestigious journal. At the same time, the review can use the automated, short-fuse offers to capture an occasional windfall piece.

One might object on the ground that it appears I fail to take account of an important reputational cost to the strategy that adopting law reviews would bear. Specifically, it could-one imagines - harm a journal's reputation as a serious scholarly venue to be seen to choose articles on grounds other than the reasoned, substantive consideration of their content. This strikes me as incorrect, on two counts. First, student-edited law reviews do not have as far to fall, in reputation, as this critique may suppose. Many student law review members do an excellent job, and the law review process has led to many a good article becoming even better. At the same time, however, there are myriad

\footnotetext{
${ }^{10}$ Perhaps the pipeline providers, such as ExpressO and Scholastica, could include this functionality to law reviews, much as they have provided expedited-review-request functionality for authors.

${ }^{11}$ The individualized offers, by contrast, are at least somewhat probative of the article's substantive merit. See Saunders, supra note 6, at 1666 n.12 (reasoning that, by existing norms, an expedite request "alerts editors at the preferred law review [receiving the request] that the article is probably worth publishing (since the editorial board of a competing law review clearly believes so)").
} 
trenchant law-professor critiques of the inanity, at some level, of having our 2Ls serve as the most significant gatekeepers of legal scholarship's publishing potential. Second, the worry about loss of law-review reputation makes a quaint category mistake. The process for pairing publications to publishing slots is not a dispassionate philosophical inquiry by a convocation of Oxford dons. ${ }^{12}$ It is simply a self-interested matching market, where nearly every piece finds a spot to rest when, as it were, the music stops. The market imperatives are candor, speed, and self-interest, not deep intellectual engagement as such. ${ }^{13}$ So long, then, as a journal is open about the process I have describedand there is no reason to conceal it-the journal's reputation will suffer not at all.

Alternatively, one might object on the ground that this strategy, were it to be widely adopted among the general law reviews outside the top 20 or 30 law schools, would disrupt the smooth functioning of the current manuscript market. Specifically, one might worry that, as more law reviews use automated offers of publication, the received-an-offer signal becomes too noisy to be of use to the more prestigious journals, many of whom reputedly rely heavily on expedite requests to help set their reading agendas. ${ }^{14}$ To this I can only respond that I have sought to follow the internal logic of the manuscript market to its natural conclusion. If less prestigious journals follow the strategy I describe, which is in their own interests, I am sure the matching market will adapt effectively rather than simply unravel. ${ }^{15}$ Whether there is a different, less resolutely market-based conception according to which to organize the manuscript sorting and selection process, I cannot say. ${ }^{16}$

\footnotetext{
${ }^{12}$ See generally Dan Subotnik, A Law Review Editor and Faculty Author Learn to Speak Honestly, 32 TOURO L. REV. 441 (2016).

${ }^{13}$ To riff on Mencken, law professors know what they want-unflinching self-interest-and deserve to get it good and hard.

${ }^{14}$ See Carl Tobias, Manuscript Selection Anti-Manifesto, 80 CORNELl L. REV. 529, 534 (1995) ("Editors of most elite reviews frequently do not read manuscripts until writers call with an offer. A number of journals ask the offeror's identity, and a few even refuse to expedite review absent that information. These editors seem content to let less prestigious journals perform initial screens, in the apparent belief that only a narrow field of high quality manuscripts will eventually float to the apex of the hierarchy."); William C. Whitford, The Need for an Exclusive Submission Policy for Law Review Articles, 1994 WIS. L. REV. 231, 231 ("Among authors it is widely believed that the 'top' reviews, such as those at Harvard or Yale, will not look at a manuscript unless the author is already famous (e.g., Richard Posner or Lawrence Tribe), or until the manuscript has been accepted at a respectable law review.").

${ }^{15}$ Contra Grimmelmann, supra note 2, penultimate paragraph: "If we looked at law review placement only by asking what authors and law reviews want individually, the entire system would collapse, and would deserve to."

${ }^{16}$ Contra Joseph Scott Miller, The Immorality of Requesting Expedited Review (Apr. 8, 2016), available at http://ssrn.com/abstract=2743299. But see also Jonathan Swift, Preface, in The Battle of the Books (1704) ("Satire is a sort of glass wherein beholders do generally discover everybody's face but their own ... .").
} 